\title{
RATIONAL NUTRITION AS A PART OF RECOVERY MEASURES FOR INCREASED PHYSICAL LOADS
}

\begin{abstract}
The article is devoted to the problem of organizing a balanced diet of student youth who are engaged in active sports. The authors of the article conducted a general analysis of problematic aspects of the organization of these types of nutrition of young athletes, considered current trends in demand for certain types of sports functional foods and recommendations of domestic and foreign experts to address relevant issues. The study of modern experience in the organization of diets of professional athletes allowed to determine the basic principles of building an adequate diet of modern athletes and formulate practical recommendations with certain sets of quantitative and qualitative characteristics of certain types of food that are most suitable for athletes engaged in various active sports. During the formulation of the relevant recommendations, the peculiarities of the course of physiological processes in the body of a person who experiences different types of sports load were taken into account. These loads impose additional requirements on the human body, the observance of which depends on the general state of health and well-being of athletes both during training and during the performance of daily activities related to human life. Based on the understanding of these factors, during the study a questionnaire survey of young athletes was conducted to determine: the general eating habits of modern youth; used diets both during training and during rest; the most popular foods and favorite dishes made from them.

Statistical processing of the results of the survey showed a high degree of awareness of students about the importance of balanced diets and the most important food components, the consumption of which affects the likelihood of achieving sports results. It was found that most young people prefer specialized functional products of targeted action, in particular, a variety of protein shakes and gainers, as well as so-called "sports" chocolate bars with different recipes. They are based on carbohydrate-protein mixtures with a certain ratio of simple and complex carbohydrates, which are further enriched with certain types of amino acids, vitamins, as well as creatine, trace elements and unsaturated fatty acids. At the same time, the analysis of the results of the survey of young athletes and the relationship of these data with modern experience in the organization of diets of professional athletes revealed a number of issues that require additional research. Addressing these issues will contribute to more efficient consumption by athletes not only of specialized foods, but also of the simplest, most common components of the human diet. Their combined consumption together with specialized foods will help to achieve the most optimal state of the body with a variety of sports activities and, if necessary, will significantly reduce the degree of consumption by athletes of specialized sports products. That is why the authors analyzed modern sports carbohydrate-protein mixtures and identified the most optimal ratio of simple and complex carbohydrates in them, determined the rational ratio of amino acids, vitamins, creatine, trace elements and unsaturated fatty acids in appropriate mixtures designed to optimize the course of physiological processes before and after sports activities of the body. Based on the modern experience of organizing the diets of professional athletes, recommendations were formulated for the use of both specialized and conventional foods in the diet of young athletes and recommendations were given to adjust the overall diet of young people who lead an active lifestyle.
\end{abstract}

Key words: food system, athletes, students, rational nutrition.

\section{Introduction}

Modern sport is a complex system of interconnected and equivalent components such as training, rest, recovery and nutrition. The development of a multi-stage training program for athletes is based on modern advances in human anatomy and physiology as the basis of anabolic processes in the human body, as well as on the results of chemistry and biochemistry as the foundations of the food industry. At present, no sporting achievement can be obtained without a properly organized diet of the athlete, without the selection of specialized foods. This is important not only for achieving significant sports results, but also for maintaining the health of a person who exposes his body to long-term exercise.

Literary review

Highly professional trainers have always paid special attention to the issue of a properly organized nutrition system. Thus, the founder of bodybuilding D. Vader considered it impossible to achieve a significant sports result only through a properly planned training system and recommended the mandatory preparation of an individual diet for each athlete, taking into account the physiological needs of calories and basic nutraceuticals [1]. For example, for gaining muscle mass, he recommended six meals with three-hour breaks between meals, as well as taking protein supplements between meals or after each meal. J. Vader's famous student Arnold Schwarzenegger fully supported this view, and in his sports career further developed it, increasing the amount of recommended additional protein nutrition to achieve maximum sports results [2].

Excessive physical activity requires athletes to in crease endurance and efficiency, so when organizing the 
nutrition system there are increased requirements not only to the diet itself, but also to the qualitative and quantitative composition of diets. Many authoritative domestic and foreign specialists worked on this problem. For example, Rosenblum K.A., Ellen Co-Lehmann [3, 4] in their works argued that the secret of endurance and high performance of the athlete is to adhere to a drinking regime and the use of dietary supplements, especially for dynamic sports.

Analysis of foreign and domestic experience in the organization of nutrition of professional athletes, conducted by Borisova O.O. [5], allowed to identify the basic principles of building an adequate diet of modern sports shift and to form practical recommendations with specific requirements for quantitative and qualitative characteristics of nutrition, depending on the peculiarities of metabolic processes in the bodies of people involved in various sports.

Pavlova Yu. and Vynohradsky B. [6] in their monograph gave an in-depth analysis of the state of fatigue that occurs after training. Using basic physiological criteria, they assessed the causes of fatigue mechanisms and their degree. These authors studied the known medical-biological, psychological and pedagogical ways to restore physical shape, especially highlighting the role of nutrition and its individual components in the process of restoring the body after exercise.

Research of Batyrev M., Batyreva T. [7], Karelina A.O. [8] and Boyko E.A. [9] also showed the dependence of sports performance on proper and rational nutrition. This problem affects not only athletes but all young people in general.

Modern young people lead an active lifestyle and due to life circumstances and their own choice are forced to combine multifaceted physical activity with an active student life, which also provides additional mental load.

That is why, according to Matveeva Zh.N. [10], the problem of properly organized nutrition is particularly acute for student youth, forced to combine physical activity with mental, which is due to learning. In her work, she considers nutrition as an integral part of recovery measures during increased physical activity, paying special attention to the need and ability to control body weight.

According to the famous sports doctor Frederick K. Hatfield [11], for athletes who conduct intensive training, the ratio of nutrients should be: proteins - 30.. 40\%, fats $-15 \ldots 20 \%$, carbohydrates $-40 \ldots 50 \%$. D. Vader [1] recommended the following ratio: proteins $-25 \ldots 30 \%$, fats - 10.. 20\%, carbohydrates - 55.. 60\%. According to Karelin A.O. [8], Likhodeeva V.A. [12], Pshendina P.I. [13], Udalova Y.F. [14] and Shestopalova S.V. [15], specialists in the field of sports nutrition and sports medicine, the recommended ratios fully meet the physiological needs of the athlete.

It is known that only food is the main source of essential nutrients, the need for which athletes have much higher than other categories of the population. It is impossible to disagree with Aranson M.V., who claims [1] that with the help of properly selected food the athlete solves the following tasks:

- ensuring a sufficient supply of calories, nutrients, trace elements and vitamins, depending on the spe- cific tasks at this stage;

- activation and normalization of metabolic processes using biologically active nutrients and additives;

- body weight preservation or change in the desired direction;

- change in body composition by increasing muscle mass and reducing the fat layer;

- creating or maintaining an optimal hormonal background to realize physical capabilities and achieve maximum results.

The solution of these problems will be facilitated by the adjustment of the diet taking into account not only physical activity, but also modern achievements of nutrition in this direction.

\section{Formulation of the problem}

The purpose of the study is to develop recommendations for the nutrition of young people who are actively involved in amateur or professional sports, based on the analysis of research results, questionnaires of students on nutrition, as well as the development of recommendations for nutrition of students-athletes.

\section{Materials and methods}

The applied research methods consisted in the analysis of scientific-methodical and special literature, documentary materials, as well as in the statistical processing of the results of the questionnaire.

\section{Results of the study and their discussion}

In the course of the research, a questionnaire survey was conducted among students engaged in amateur or professional sports on nutrition preferences and the organization of a balanced sports diet. Students of 2-4 courses of the Odessa National Academy of Food Technologies aged 18 to 21 took part in the survey. During the study, the method of testing was used to determine students' awareness of proper nutrition and types of eating disorders. The method of questionnaires determined the features of eating behavior and food preferences. Statistical processing of the results showed a high degree of awareness of students, especially athletes, about a rational and balanced diet, the importance of the main food components in achieving athletic performance. At the same time, more than $70 \%$ of surveyed students did not follow the principles of a balanced diet and regular eating habits. Most of the surveyed young people eat unsystematically, and even among athletes only about $65 \%$ of all respondents meet the requirements of a strict diet with the recommended intervals, frequency and volume of single meals.

The survey of food preferences among studentathletes showed the priority of products of animal origin - more than $80 \%$ and in this group the leading positions were taken by meat and dairy products, fish products were less than $10 \%$. Of the carbohydrate products, more than $60 \%$ of respondents preferred sugar and flour confectionery, more than $20 \%$ preferred cereals, in particular, rice, buckwheat and about $10 \%$ - potatoes. As an express food, more than $80 \%$ of athletes preferred specialized sports nutrition products with targeted action protein shakes, gainers and "sports" bars of various recipes.

Gainers are carbohydrate-protein mixtures with 
the optimal ratio of simple and complex carbohydrates, enriched with amino acids, vitamins, creatine, trace elements and unsaturated fatty acids, designed to optimize the physiological processes occurring in the body after exercise. They have long been positively established as additional sports nutrition and are in high demand among athletes. In addition, these protein-carbohydrate drinks stimulate insulin secretion, improving the degree and rate of assimilation of proteins, fats and carbohydrates. At the same time, their incorrect use, for example, just before training, causes drowsiness and reduced efficiency, due to the "release" of insulin into the blood while taking a significant amount of "fast" carbohydrates. Gainers, like any other carbohydrate, can be consumed no later than $1 \ldots 1.5$ hours before training and in $15 . .30$ minutes after training. Before training, they create an optimal energy background and increase the intramuscular supply of free amino acids, which are actively exchanged under heavy loads. The carbohydrate composition of gainers provides a long-lasting effect and allows you to quickly and efficiently restore the energy reserves of cells, create the conditions for recovery and build muscle. Gainers promote rapid weight gain, which is perceived by most consumers as a side effect. Daily intake of 2-3 servings of gainer provides a set of at least $5 \mathrm{~kg}$ per month. Therefore, to consume gainers on days off from training is recommended for athletes, who have difficulties about building muscle mass, as well as to increase the caloric content of food and accelerate the recovery process in the body of athletes after training. You can use a gainer to enlarge muscle mass by increasing its protein component by additional intake of individual amino acid complexes or complex proteins. All gainers differ in the ratio of carbohydrates to proteins. The traditional ratio is $3: 1$, there are mixtures with a ratio of 1: 1 and 5: 1, but the optimal ratio is 2: 1. In addition, gainers can be used in conditions of irregular and poor nutrition, which is common among students. Gainers are also widely used among tourists and fans of extreme activities.

In the presence of excess adipose tissue, it is recommended to use so-called fat burners - lipotropic and thermogenic substances, such as caffeine, L-carnitine and chitosan. Caffeine itself does not promote the breakdown of fat, but enhances the action of other components; in addition, it stimulates the central nervous system and improves endurance. One of the most available sources of caffeine is green tea. L-carnitine is a natural amino acid that is synthesized in the liver and kidneys and enters the body along with proteins of animal origin. Additional intake of L-carnitine not only stops the growth of fat cells and increases the oxidation of fatty acids in the cell, but also accelerates the recovery process after exercise. Chitosan is obtained from sea shells and crab shells. It is an excellent adsorbent; in addition, it has the ability to bind fats before they enter the bloodstream through the digestive tract, thereby reducing the assimilation of fatty foods, enhancing the breakdown of reserve fats and promoting the removal of excess fluid from the body. Today, chitosan is actively used as an unconventional additive in the production of canned and confectionery products.

Table 1 - Relationship of different types of food with the term of their digestion

\begin{tabular}{||c||c||}
\hline \hline Duration of digestion & Types of food \\
\hline \hline $1-2$ hours & $\begin{array}{c}\text { Water (including mineral), juices, tea, cocoa, coffee (including milk), milk (not condensed), } \\
\text { dairy products (including yogurt), soft-boiled eggs, broth, rice boiled, boiled fish, cereals. }\end{array}$ \\
\hline \hline $2-3$ hours & $\begin{array}{c}\text { Coffee with cream, hard-boiled eggs, scrambled eggs, omelet, boiled meat, boiled potatoes, } \\
\text { wheat bread, pasta, etc. }\end{array}$ \\
\hline \hline $3-4$ hours & $\begin{array}{c}\text { Boiled poultry, rye bread, cucumbers, radishes, cabbage and other vegetables, fried pota- } \\
\text { toes, ham, sausage, apples, bananas and other fruits. }\end{array}$ \\
\hline \hline 4-5 hours & Roasted meat of mammals and birds, peas, beans and legumes, herring and marinades. \\
\hline \hline $6-7$ hours & Lard, mushrooms. \\
\hline
\end{tabular}

Table 2 - Conditions and place of digestion of the main food ingredients

\begin{tabular}{|c|c|c|c|}
\hline \multirow[b]{2}{*}{ Types of food ingredients } & \multirow[b]{2}{*}{ The main place of digestion } & \multicolumn{2}{|l|}{ Conditions of digestion } \\
\hline & & Enzymes & $\begin{array}{l}\mathrm{pH} \text { of the } \\
\text { medium }\end{array}$ \\
\hline Proteins & Stomach. & Pepsin, renin, chymosin, gastrixin. & $\begin{array}{l}1,5-2,5 \\
2,5-4,5\end{array}$ \\
\hline Proteins & $\begin{array}{l}\text { The upper parts of the small } \\
\text { intestine and duodenum. }\end{array}$ & $\begin{array}{l}\text { Proteolytic pancreatic enzymes trypsin, } \\
\text { chymotrypsin, carboxypolypeptidase and } \\
\text { proelastase. }\end{array}$ & $7,5-8,2$ \\
\hline Fats & Small intestine. & Lipase. & $7,5-8,2$ \\
\hline \multirow[b]{2}{*}{ Carbohydrates } & Oral cavity. & Amylase, maltose. & $7,5-8,2$ \\
\hline & Small intestine. & $\begin{array}{l}\text { Amylase, maltose, sucrose, lactase, } \\
\text { dextrinase. }\end{array}$ & $7,5-8,2$ \\
\hline $\begin{array}{l}\text { Hot water, carbonated wa- } \\
\text { ter, alcohol. Ordinary and } \\
\text { mineral water. Water as a } \\
\text { part of a food komkahimus. }\end{array}$ & $\begin{array}{l}\text { Stomach. } \\
\text { Upper parts of the small } \\
\text { intestine. } \\
\text { Colon. }\end{array}$ & Temperature and presence of $\mathrm{CO}_{2}$ & $\begin{array}{l}1,5-3,5 \\
7,5-8,2 \\
7,5-8,2\end{array}$ \\
\hline
\end{tabular}


Table 3 -Chemical composition and energy value of basic food products

\begin{tabular}{|c|c|c|c|c|}
\hline \multirow{2}{*}{ Food } & \multicolumn{3}{|c|}{ Chemical composition, g / 100g of product } & \multirow{2}{*}{$\begin{array}{c}\text { Caloric content } \\
100 \Gamma \\
\end{array}$} \\
\hline & Proteins & Fats & Carbohydrates & \\
\hline Meat of mammals, birds and products from it & $12-21$ & $2-37$ & - & $101-380$ \\
\hline Fish, fish products & $13-19$ & $1-16$ & - & $60-196$ \\
\hline Dairy products & $3-4$ & $0,5-6$ & $3-6$ & $30-60$ \\
\hline Cheese & $14-31$ & $9-32$ & - & $209-400$ \\
\hline Sour milk cheese and curds based on it & $7-18$ & $1-26$ & $1-1,5$ & $86-375$ \\
\hline Eggs & $12-13$ & $11-12$ & 0,7 & - \\
\hline Soy & 35 & 17 & 26 & 395 \\
\hline Beans & $20-25$ & $1-1,7$ & $26-55$ & $304-329$ \\
\hline Fresh mushrooms & $3-24$ & $0,5-0,9$ & $2-4$ & $19-31$ \\
\hline Cereals, pasta & $7-13$ & $0,5-7,0$ & $58-75$ & $320-340$ \\
\hline Nuts & $18-25$ & $53-58$ & 7,5 & $600-700$ \\
\hline Bread and bakery products & $5-10$ & $1-12$ & $40-73$ & $190-330$ \\
\hline Fats, oils, creesh, lard & $0-0,3$ & $82-99,9$ & - & $740-899$ \\
\hline Vegetables and fruits & $0,5-3,0$ & $0,1-0,4$ & $\overline{5-11}$ & $10-91$ \\
\hline
\end{tabular}

Properly organized nutrition system prevents the unwanted effect of drowsiness or low levels of athletic performance. For example, knowledge of the duration and conditions of food digestion and the energy potential of their consumption allow you to adjust the intervals between meals and exercise, as well as adjust the intensity of exercise.

The following tables group three categories of indicators, taking into account which allows you to balance the main indicators of any diet and more fully understand the relationship of different types of food with the term of their digestion in the human body (see Table 1), conditions and place of digestion basic food ingredients (see Table 2) and the chemical composition and energy value of basic food products (see Table 3). Here it should be emphasized once again that even a general understanding of the dependences listed in table 1-3 and taking into account the relevant physiological indicators allows anyone to balance their diet, and young athletes - to increase both sports and daily efficiency with regular physical and mental loads. At the same time, regular and systematic consumption of simple foods is the most favorable factor not only for achieving good fitness, but also good health.

\section{Conclusions}

Thus, information about the chemical composition of basic foodstuffs, conditions, location and duration of digestion in the digestive system allows correctly make a physiologically reasonable, complete and balanced diet taking into account the intensity and frequency of loading of an athlete.

The prospect of further research in this direction is to develop personalized diets for athletes depending on the sport and their planned training load.

\section{REFERENCES}

1. Vejder, Dzho. (1992). Sistema stroitelstva tela. Moscow: «Fizkultura i sport». $-112 p$.

2. Shvarcenegger, Arnold. (2000). Novaya enciklopediya bodibildinga. Moscow: Eksmo-press. -790 p.

3. Koleman, Elen. (2005). Pitanie dlya vynoslivosti: Perevod s angliskogo. Murmansk: «Tuloma». - 190 p.

4. Rozenblyum, K.A. (2006). Pitanie sportsmenov Kiev: NUFVSU Olimpijskaya literatura. -535 p.

5. Borisova, O.O. (2007). Pitanie sportsmenov: zarubezhnyj opyt i prakticheskie rekomendacii: Uchebno-me-todicheskoe posobi. Moscow: Sovetskij sport. -132 p.

6. Pavlova, Yu., Vinogradskij, B. (2011). Vidnovlennya u sporti: Monografiya. - Lviv: LDUFK. - 204 p.

7. Batyrev, M.E., Batyreva, T.F. (2005). Sportivnoe pitanie. - Saint Petersburg: Piter. - 144 p.

8. Karelin, A.O. (2005). Pravilnoe pitanie pri zanyatiyah sportom i fizkulturoj. Saint Petersburg: Dilya. $-256 \mathrm{p}$.

9. Bojko, E.A. (2006). Pitanie i dieta dlya sportsmenov. Moscow: Veche. -176 p.

10. Matveeva, Zh.N. (1999). Racionalnoe pitanie i ispolzovanie vosstanovitelnyh meropriyatij pri povyshennyh fizicheskih nagruzkah. Kontrol za vesom tela. Novgorod: MO i ORF, NGU im. Yaroslava Mudrogo. -25 p.

11. Hetfild, Frederik K. (1992). Vsestoronnee rukovodstvo po razvitiyu sily. Krasnoyarsk: Izdano associaciej federacij kulturizma Vostochnoj Sibiri i Dalnego Vostoka "Vostok". - 288 p.

12. Lihodeeva, V.A. (2004). Osobennosti adaptacii i obmena veshestv pri myshechnoj deyatelnosti: Uchebnoe posobie dlya studentov. Volgograd. $-31 \mathrm{p}$.

13. Pshendin, P.I. (2005). Racionalnoe pitanie sportsmenov. Moscow: F i S. -74 p.

14. Udalov, Yu.F. (2005). Biohimiya myshechnoj deyatelnosti: Uchebnoe posobie. Malahovka: MGAFK. - $236 \mathrm{p}$.

15. Shestopalov, S.V. (2000). Bodibilding. Rostov na Donu: «Profi-Press». - 192 p. 
С.Н. Павловський, канд. техн. наук, доцент, E-mail: pavlovskijs80@gmail.com https://orcid.org/0000-0001-5701-8031

Одеська національна академія харчових технологій вул. Канатна, 112, 65039 м. Одеса, Україна, Теl. +38048 7124078

\section{РАЦІОНАЛЬНЕ ХАРЧУВАННЯ ЯК СКЛАДОВА ЧАСТИНА ВІДНОВЛЮВАЛЬНИХ ЗАХОДІВ ПРИ ПІДВИЩЕНИХ ФІЗИЧНИХ НАВАНТАЖЕННЯХ}

\section{Анотація}

Стаття присвячена проблемі організачії збалансованого рачіонального харчування студентської молоді, яка займається активними видами спорту. Авторами статті проведено загальний аналіз проблемних аспектів організації зазначених типів харчування молодих спортсменів, розглянуті сучасні тендениії попиту на певні види спортивних функціональних продуктів харчування та наведені рекомендації вітчизняних $i$ закордонних фахівців щзодо вирішення відповідної проблематики. Вивчення сучасного досвіду в організації раціонів харчування професійних спортсменів дозволило визначити основні принципи побудови адекватного раціону сучасного спортсмена та сформулювати практичні рекомендації з певними наборами кількісних $і$ якісних характеристик окремих типів харчування, які є найбільш придатними до застосування спортсменами, щзо займаються різними видами активного спорту. Під час формулювання відповідних рекомендачій були враховані особливості протікання фізіологічних прочесів в організмі людини, щчо піддає свій організм різним видам спортивного навантаження. Ці навантаження накладають на організм людини додаткові вимоги, від дотримання яких залежить загальний стан здоров'я $і$ самопочуття спортсменів як під час тренувань, так $i$ впродовж виконання повсякденних дій, пов'язаних із життєдіяльністю людини.

Базуючись на розумінні ичих факторів, під час дослідження було проведено анкетне опитування молодих спортсменів з метою визначення: загальних харчових звичок сучасної молоді; використовуваних режимів харчування як в період тренувань, так й під час відпочинку; найбільш популярних продуктів харчування та улюблених страв, виготовлених з них. Статистична обробка отриманих результатів опитування показала високий ступень інформованості студентів про значення збалансованих раціонів харчування та найбільи важливих харчових складових, споживання котрих впливає на імовірність досягнення спортивних результатів. Було виявлено, щчо найбільшою мірою молодь віддає перевагу спеціалізованим продуктам функиіонального призначення спрямованої дї, зокрема, різноманітним протеїновим коктейлям та гейнерам, а також так званим “спортивним” шоколадним батончикам із різним рецептурним складом. В їх основу покладені вуглеводнобілкові суміші з певним співвідношенням простих та складних вуглеводів, щьо додатково збагачені окремими видами амінокислот, вітамінів, а також креатином, мікроелементами і ненасиченими жирними кислотами.

В той же час, аналіз отриманих результатів опитування молодих спортсменів та співвідношення циих даних із сучасним досвідом в організащії раџіонів харчування професійних спортсменів дозволив виявити низку питань, щчо потребують додаткового дослідження. Вирішення ичих питань сприятиме більш ефективному споживанню спортсменами не тільки спеціалізованих продуктів харчування, але й простих, найбільш поширених натепер складових раціону людини. Їхнє комбіноване споживання разом із спеціалізованими продуктами харчування сприятиме досягненню найбільш оптимального стану організму при різноманітних спортивних навантаженнях та при потребі дозволить значною мірою скоротити ступень споживання спортсменами спеціалізованих спортивних продуктів. Саме тому авторами був проведений аналіз сучасних спортивних вуглеводно-білкових сумішей та виявлене найбільш оптимальне співвідношення простих і складних вуглеводів в них, визначено раціональне співвідношення амінокислот, вітамінів, креатину, мікроелементів і ненасичених жирних кислот у відповідних сумішах, щчо призначені для оптимізації протікання фізіологічних процесів до та після спортивних навантажень організму. Спираючись на сучасний досвід організації раціонів харчування професійних спортсменів, були сформульовані рекомендації до застосування як спеціалізованих, так $i$ звичайних продуктів харчування у ращіоні молодих спортсменів та надані рекомендації щзодо корегування загальної структури харчування молоді, яка веде активний спосіб життя.

Ключові слова: система харчування, спортсмени, студенти, раціональне харчування.

\section{ЛITЕРАТУРА}

1. Вейдер, Джо. Система строительства тела [Текст] / Джо Вейдер. - М.: Изд-во «Физкультура и спорт», 1992. $112 \mathrm{c}$.

2. Швариенеггер, Арнольд. Новая энииклопедия бодибилдинга [Текст] / Арнольд Швариенеггер. - М.: Эксмо-пресс, 2000. $-790 c$.

3. Колеман, Элен. Питание для выносливости [Текст]: Перевод с англиского / Элен Колеман. - Мурманск: «Тулома», 2005. - 190c

4. Розенблюм, К.А. Питание спортсменов [Текст] / К.А. Розенблюм. - К.: НУФВСУ Олимпийская литература, 2006. $-535 c$ 
5. Борисова, О.О. Питание спортсменов: зарубежный опыт и практические рекомендации [Текст]: Учебно- методическое пособие / О.О. Борисова. - М.: Советский спорт, 2007. - 132 c.

6. Павлова, Ю., Виноградський, Б. Відновлення у спорті [Текст]: монографія / Ю. Павлова, Б. Виноградський. - Л.: ЛДУФК, 2011. - 204 c.

7. Батырев, М.Е. Спортивное питание [Текст] / М.Е. Батырев, Т.Ф. Батырева. - СПб: Питер, 2005. - 144 c.

8. Карелин, А.О. Правильное питание при занятиях спортом и физкультурой [Текст] / А.О. Карелин. - СПб.: Диля, 2005. $-256 c$.

9. Бойко, Е.А. Питание и диета для спортсменов [Текст] / Е.А. Бойко. - М.: Вече, 2006. - 176 c.

10. Матвеева, Ж.Н. Рациональное питание и использование восстановительных мероприятий при повышенных физических нагрузках. Контроль за весом тела [Текст] / Ж.Н. Матвеева. - Новгород: МО и ОРФ, НГУ им. Ярослава Мудрого, 1999. - 25 c.

11. Хэтфилд, Фредерик К. Всестороннее руководство по развитию силь [Текст] / Фредерик К. Хэтфилд. - Красноярск: Издано ассоџиаџией федераџий культуризма Восточной Сибири и Дальнего Востока "Восток", 1992. - 288c.

12. Лиходеева, В.А. Особенности адаптации и обмена веществ при мышечной деятельности [Текст]: учебное пособие для студентов / В.А. Лиходеева. - Волгоград, 2004. - 31 с.

13. Пшендин, П.И. Рациональное питание спортсменов [Текст] / П.И. Пшендин. - М.: Фи С, 2005. - 74 с.

14. Удалов, Ю.Ф. Биохимия мышечной деятельности [Текст]: учебное пособие / Ю.Ф. Удалов, Л.П. Михеева. - Малаховка: МГАФК, 2005. - $236 \mathrm{c}$.

15. Шестопалов, С.В. Бодибилдинг [Текст] / С.В. Шестопалов. - Ростов на Дону: «Профи-Пресс», 2000. - 192 с.

Received 26.11.2020

Reviewed 19.12.2020
Revised 23.01.2021

Approved 30.03.2021

Cite as Vancouver Citation Style

Salavelis A., Pavlovsky S. Rational nutrition as a part of recovery measures for increased physical loads. Grain products and mixed fodder's, 2021; 21 (1,81): 15-20. DOI https://doi.org/

Cite as State Standard of Ukraine 8302:2015

Rational nutrition as a part of recovery measures for increased physical loads / Salavelis A. et al. // Grain Products and Mixed Fodder's. 2021. Vol. 21, Issue 1 (81). P. 15-20. DOI https://doi.org/

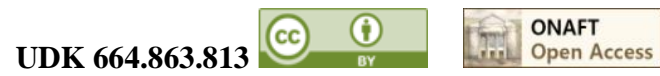

${ }^{1}$ Wang Haiyan, 2nd year master student of the Faculty of Food Technology, E.mail:2271651023@qq.com

${ }^{1}$ Melnyk Oksana, Asociate Professor, E.mail: Oksana.Melnyk@snau.edu.ua https://orcid.org/0000-0002-9201-7955, Researcher ID: V-9901-2018, Scopus 57214797466

${ }^{1}$ Sumy National Agrarian University, 180, G. Kondratiev Str., Sumy, 40021, Ukraine

${ }^{2} \mathrm{Li}$ Bo, Doctor Sciences, Professor

${ }^{2}$ Henan Institute of Science and Technology, China

\section{FUNCTIONAL DRINK TECHNOLOGY WITH CHIA SEEDS}

\footnotetext{
Abstract

This article mainly introduces the necessity of the emergence of functional foods and the current market development. Using chia seeds as the characteristic raw material, adding apple juice and hawthorn juice, it is developed to be suitable for subhealthy people, obese people, diabetes and cardiovascular patients.

Functional beverages refer to beverages that regulate human body functions to a certain extent by adjusting the composition and content ratio of nutrients in the beverage. In recent research hotspots, chia seeds are often developed and applied by nutritionists or other nutrition enthusiasts because of their rich nutritional value. Chia seeds are rich in a variety of unsaturated fatty acids, accounting for about $80 \%$ of the total fatty acid content, of which omega-3 and omega- 6 unsaturated fatty acids are the most content, $68 \%$ is $\alpha$-linolenic acid, which is the most abundant omega-3 fatty acid content of the food. Each $100 \mathrm{~g}$ of chia seeds contains about 16-25g of protein and about 26-40g of dietary fiber, including all 8 amino acids needed by the human body. In addition, it is also rich in vitamins and minerals, as well as a variety of natural antioxidant ingredients, with high-quality antioxidant functions. This makes the ability of chia seeds to maintain blood sugar stability, protect the heart, cerebrovascular, and promote gastrointestinal motility and bone health cannot be underestimated.

Hawthorn contains a large amount of vitamin C, carotene, organic acids and other nutrients, combined with cellulose, pectin and organic acids in apples, can further assist chia seeds to improve gastrointestinal conditions and promote gastrointestinal motility, while soluble fiber Vegetarian can regulate blood sugar.

This article chooses apple and hawthorn as flavor bases, oligosaccharides (FOS) as sweeteners, resistant starch and guar gum as composite stabilizers, to produce a chia seed functional drink to reduce weight and improve heart and brain Vascular health problems. In the extremely poor analysis of the orthogonal test results of the chia seed functional drink, the best sample formula.

Keywords: chia seeds; starch; fructose; functional food; functional drinks; weight loss; cardiovascular and cerebrovascular health.
} 